\title{
Activities of indigenous proteolytic enzymes in caprine milk of different somatic cell counts
}

\author{
M. Albenzio, ${ }^{* 1}$ A. Santillo, ${ }^{*}$ A. L. Kelly, $\dagger$ M. Caroprese, ${ }^{*}$ R. Marino, ${ }^{*}$ and A. Sevi ${ }^{*}$ \\ *Department of the Sciences of Agriculture, Food and Environment (SAFE), University of Foggia, Via Napoli, 25, 71100 Foggia, Italy \\ †School of Food and Nutritional Sciences, University College, Cork, Ireland
}

\begin{abstract}
Individual caprine milk with different somatic cell counts (SCC) were studied with the aim of investigating the percentage distribution of leukocyte cell types and the activities of indigenous proteolytic enzymes; proteolysis of casein was also studied in relation to cell type following recovery from milk. The experiment was conducted on 5 intensively managed dairy flocks of Garganica goats; on the basis of SCC, the experimental groups were denoted low (L-SCC; $<700,000$ cells $/ \mathrm{mL}$ ), medium (M-SCC; from 701,000 to 1,500,000 cells/mL), and high (H-SCC; >1,501,000 cells/mL) SCC. Leukocyte distribution differed between groups; polymorphonuclear neutrophilic leukocytes were higher in M-SCC and $\mathrm{H}-\mathrm{SCC}$ milk samples, the percentage macrophages was the highest in H-SCC, and levels of nonviable cells significantly decreased with increasing SCC. Activities of all the main proteolytic enzymes were affected by SCC; plasmin activity was the highest in H-SCC milk and the lowest in L-SCC, and elastase and cathepsin $\mathrm{D}$ activities were the highest in M-SCC. Somatic cell count influenced casein hydrolysis patterns, with less intact $\alpha$ - and $\beta$-casein in H-SCC milk. Higher levels of low electrophoretic mobility peptides were detected in sodium caseinate incubated with leukocytes isolated from L-SCC milk, independent of cell type, whereas among cells recovered from M-SCC milk, macrophages yielded the highest levels of low electrophoretic mobility peptides from sodium caseinate. The level of high electrophoretic mobility peptides was higher in sodium caseinate incubated with polymorphonuclear neutrophilic leukocytes and macrophages isolated from MSCC, whereas the same fraction of peptides was always the highest, independent of leukocyte type, for cells recovered from H-SCC milk. In caprine milk, a level of 700,000 cells/mL represented the threshold for changes
\end{abstract}

Received April 29, 2015

Accepted July 14, 2015.

${ }^{1}$ Corresponding author: m.albenzio@unifg.it in leukocyte distribution, which is presumably related to the immune status of the mammary gland. Differences in the profile of indigenous lysosomal proteolytic enzymes in caprine milk may influence the integrity of casein based on proteolysis patterns of sodium caseinate incubated with isolated and lysed leukocyte types. Key words: caprine milk, plasmin, cathepsin D, elastase, leukocyte cell type

\section{INTRODUCTION}

In the European Union, Regulation 853/2004, which specifies hygiene rules for food of animal origin (EU, 2004), states that raw bovine milk must have a SCC lower than or equal to 400,000 cells/mL. The systematic extrapolation of findings from investigations on cows to small ruminants leads to errors in the application of discriminatory standards for sheep and caprine milk quality (Raynal-Ljutovac et al., 2007). Cows produce milk by the merocrine process, whereas goats secrete milk through the apocrine process; therefore, caprine milk typically has a naturally higher SCC than bovine milk. For ovine milk, Sevi et al. (1999) suggested a threshold of 700,000 cells/mL for bulk milk of satisfactory hygienic and processing quality; Albenzio et al. (2012b) found an impairment of mammary epithelium secretory efficiency above $300,000 \mathrm{SCC} / \mathrm{mL}$ in ovine milk. The Scientific Panel on Biological Hazards of the European Food Safety Authority concluded that high SCC cannot be used as a marker of udder infection in caprine milk (EFSA, 2005). In the United States, the maximum SCC for caprine milk for commercial use has been raised to 1,000,000 cells/mL (Park and Guo, 2006; Park, 2010).

Determination of differential milk leukocyte count, together with SCC, is a potentially useful approach for gaining information on the immune status of the mammary gland. In ovine and caprine milk samples, flow cytometry has been used to detect the percentages of PMNL, macrophages, and lymphocytes (Albenzio et al., 2009, 2011; Albenzio and Caroprese, 2011; Boulaaba et al., 2011). 
The principal indigenous proteolytic enzymes in milk consist of the plasmin-plasminogen system, cathepsin $\mathrm{D}$, and elastase; these originate from blood plasma and leukocytes, and their activities are related to physiological aspects or external influences and affect milk cheesemaking properties (Albenzio et al., 2009; Moatsou, 2010). Plasmin is the predominant native proteinase in raw milk and is produced by hydrolysis of its inactive zymogen, plasminogen, by urokinase-type plasminogen activators, associated with somatic cells, or tissue-type activators, which are mainly associated with CN micelles (Politis, 1996). The second proteinase identified in milk is cathepsin $\mathrm{D}$, and its activity is associated with somatic cells (Larsen et al., 1996). Somatic cells also contain other proteolytic enzymes such as cathepsins B, L, and G and elastase (Kelly and McSweeney, 2002), which are present in lysosomes of macrophages and PMNL (Albenzio et al., 2009).

Caprine milk is largely processed into cheese, and production of such cheese is increasing; caprine milk has also been recommended as an ideal substitute for cow milk for infants and patients who suffer from cow milk allergy (Bevilacqua et al., 2001; Albenzio et al., 2012). In the dairy industry, fresh raw milk is usually stored at refrigeration temperatures before cheesemaking, and during this time, indigenous and microbial enzymes may hydrolyze CN and negatively affect the ability of milk to be processed into cheese. Few studies have focused on indigenous enzymes in caprine milk (Santillo et al., 2009), and to the best of our knowledge, no studies have been performed on the role of different leukocyte types on proteolysis in such milk.

The present study examined individual caprine milk samples with different levels of SCC with the aim of investigating the percentage distribution of leukocyte types and the activities of indigenous proteolytic enzymes. In particular, $\mathrm{CN}$ proteolysis patterns were studied in relation to leukocyte cell types isolated from caprine milk samples with different somatic cell counts.

\section{MATERIALS AND METHODS}

\section{Experimental Design and Milk Sampling Collection}

The experiment was conducted in 5 intensively managed dairy flocks of Garganica goats, located in Apulia region (southern Italy). The goats were milked twice daily in a parlor using a pipeline milking machine. Before milk collection, goats were carefully examined by a veterinarian to confirm the absence of any sign of clinical mastitis such as fever, pain, or gland swelling, and a small quantity of milk was checked visually for signs of mastitis. Animal handling followed the recommenda- tions of European Union directive 86/609/EEC concerning animal care. Milk SCC was determined using a Fossomatic Minor (Foss Electric, Hillerød, Denmark) according to the International Dairy Federation standard (IDF, 1995). Based on SCC, samples were classified as low SCC (L-SCC; <700,000 cells/mL); medium SCC (M-SCC; from 701,000 to 1,500,000 cells/mL); and high SCC (H-SCC; >1,501,000 cells $/ \mathrm{mL})$.

Four sampling cycles were performed over a 6-mo period; each sampling cycle was conducted over a 3 -wk period. At each sampling time, individual milk samples were analyzed for SCC over 3 consecutive days to verify the level of SCC over time for the same goat; on the fourth sampling day, a milk sample with similar SCC to that measured on the 3 previous days was included in the study and assigned to 1 of the 3 SCC classes.

A total of 1,600 individual caprine milk samples were randomly selected from the pool of the samples collected during milk sampling and used for the study; the number of individual caprine milk samples was 525 in the L-SCC group, 560 in the M-SCC group, and 515 in the H-SCC group. The mean SCC for each group tested was $316,234 \pm 43,000$ cells $/ \mathrm{mL}$ in L-SCC; $1,066,835$ $\pm 52,000$ cells $/ \mathrm{mL}$ in M-SCC; and 2,282,348 $\pm 53,000$ cells/mL in H-SCC.

\section{Enzymatic Assays, Differential Leukocyte Count, and Cell Isolation from Individual Caprine Milk Samples}

Plasmin and plasminogen, elastase, and cathepsin D activities were determined according to the procedures described by Albenzio et al. (2009). Cell pellets from milk samples were obtained and treated as reported by Albenzio et al. (2009). Lymphocytes, macrophages, and PMNL were selected for analysis by gating on the forward scatter and side scatter. Fluorescein isothiocyanate and R-phycoerythrin fluorescence were measured at $519 \mathrm{~nm}$ (FL1) and $578 \mathrm{~nm}$ (FL2), respectively, and fluorescence FL1 versus FL2 was used to determine the proportions of CD14/CD11b and CD14/CD5. The proportion of nonviable milk cells was determined by staining the cell pellet, resuspending in $200 \mu \mathrm{L}$ of PBS (D8537, Sigma-Aldrich, Buchs, Switzerland), with 50 $\mu \mathrm{L}$ of propidium iodide (P4864, Sigma-Aldrich; $4 \mu \mathrm{L} /$ $\mathrm{mL}$ ), and incubating for $15 \mathrm{~min}$. Samples were analyzed by flow cytometry (Cell Lab Quanta SC, Beckman Coulter Inc., Fullerton, CA), and fluorescence was measured at $617 \mathrm{~nm}$ (flow cytometric method).

Separation of macrophages, PMNL, and lymphocytes from milk somatic cells was performed according to the method of Caroprese et al. (2008) using positive magnetic separation (EasySep, StemCell Technolo- 
gies, Vancouver, Canada) with a specific monoclonal mouse IgG anti-bovine for each leukocyte class: CD5:PE (MCA2215PE, Serotec, Bio-Rad, Hercules, CA) for lymphocytes; CDllb:fluorescein isothiocyanate (MCA1425F, Serotec) for PMNL, and CD14:R-phycoerythrin-Alexa Fluor 647 (MCA1568P647T, Serotec) for macrophages. Leukocyte preparations were concentrated to obtain a final concentration of $10^{6}$ cells $/ \mathrm{mL}$ and suspended in PBS.

\section{Proteolytic Activity Against Sodium Caseinate}

After the positive magnetic separation, concentrated cells of macrophages, PMNL, and lymphocytes were lysed by at least 3 freeze-thaw cycles and incubated in Na-caseinate buffer for $4 \mathrm{~d}$ at $37^{\circ} \mathrm{C}$ at $\mathrm{pH}$ 6.5. A $4 \%$ suspension of purified goat Na-caseinate was used as a substrate to evaluate the proteolytic activity of each leukocyte cell type isolated from samples of caprine milk with different SCC. Sodium caseinate was dissolved in $0.1 M$ Tris buffer (Sigma-Aldrich), and $0.05 \%$ (wt/ vol) $\mathrm{NaN}_{3}$ was added to prevent microbial growth. The stacking and resolving gel system was prepared as described by Andrews (1983), and gels were stained with Coomassie Brillant Blue G25 by the method of Blakesley and Boezi (1977). The distained gels were scanned by the Gel Doc EQ system (Bio-Rad, Waterford, UK) using a white light conversion screen and analyzed with Quantity One software (Bio-Rad) to determine the signal intensity (optical density) of the defined bands. Identification of bands was done by comparison with a caprine Na-caseinate standard obtained according to Mulvihill and Fox (1977) and electrophoretograms reported by Albenzio et al. (2006). The relative quantity of each defined band in a single lane was determined as the percentage of the total optical density, considering as $100 \%$ the sum of the optical density measured in all bands of that lane. The low electrophoretic mobility peptides and the high electrophoretic mobility peptides represented a pool of peptides located in the upper and lower part of the gel before the $\beta$-CN bands and after the $\alpha_{\mathrm{s}} \mathrm{CN}$ bands, respectively.

\section{Statistical Analysis}

All variables were tested for normal distribution using the Shapiro-Wilk test (Shapiro and Wilk, 1965). Data were processed using ANOVA (SAS Institute Inc., 2011). The effects of SCC class on the tested variables was determined. Where significant effects were found $(P<0.05)$, a Student's $t$-test was used to determine significant differences between means. For level of intact $\mathrm{CN}$ and $\mathrm{CN}$ hydrolysis products quantified in incubated samples of sodium caseinate, samples taken after $6 \mathrm{~h}$ of incubation were used as covariates. Simple linear regression correlations between leukocyte cell types and measured activities of indigenous proteolytic enzymes were also determined.

\section{RESULTS}

The differential leukocyte count, in terms of percentage of lymphocytes, PMNL, macrophages, and nonviable PMNL, of individual caprine milk samples with different SCC are presented in Table 1. Differential leukocyte count was clearly affected by SCC; L-SCC milk samples (i.e., SCC $<700,000$ cells $/ \mathrm{mL}$ ) had the lowest percentage of PMNL and the highest percentage of lymphocytes. In samples with $>701,000$ cells $/ \mathrm{mL}$ (M-SCC and H-SCC), PMNL represented the largest proportion of cells present. The percentage of macrophages was low in all samples but highest in H-SCC; finally, the percentage of nonviable cells significantly decreased with increasing level of somatic cells.

All the indigenous proteolytic activities assayed were affected by milk SCC (Table 2); plasmin activity was highest in H-SCC and lowest in L-SCC, with a 2-fold difference in activity between these groups. Elastase and cathepsin D activities were highest in M-SCC caprine milk samples, lowest in L-SCC caprine milk samples, and intermediate in H-SCC caprine milk samples. A positive correlation was found between cathepsin D activity and PMNL level $(\mathrm{r}=0.89, P<0.01)$.

Urea-PAGE electrophoretograms of purified caprine $\mathrm{Na}$-caseinate after incubation with isolated and

Table 1. Percentage of different cell populations and nonviable PMNL in individual caprine milk samples with different levels of SCC ${ }^{1}$

\begin{tabular}{lccccc}
\hline Item & $\begin{array}{c}\text { L-SCC } \\
(\mathrm{n}=525)\end{array}$ & $\begin{array}{c}\text { M-SCC } \\
(\mathrm{n}=560)\end{array}$ & $\begin{array}{c}\text { H-SCC } \\
(\mathrm{n}=515)\end{array}$ & SEM & $\begin{array}{c}\text { Effect, } \\
P \text {-value }\end{array}$ \\
\hline Lymphocytes (\%) & $51.03^{\mathrm{b}}$ & $37.05^{\mathrm{a}}$ & $33.06^{\mathrm{a}}$ & 2.4 & $<0.001$ \\
PMNL (\%) & $42.03^{\mathrm{a}}$ & $58.07^{\mathrm{b}}$ & $60.28^{\mathrm{b}}$ & 2.4 & $<0.001$ \\
Macrophages (\%) & $4.66^{\mathrm{a}}$ & $5.72^{\mathrm{ab}}$ & $7.26^{\mathrm{b}}$ & 0.50 & $<0.001$ \\
Nonviable PMNL (\%) & $18.7^{\mathrm{c}}$ & $9.21^{\mathrm{b}}$ & $5.59^{\mathrm{a}}$ & 1.4 & $<0.001$ \\
\hline
\end{tabular}

${ }^{\mathrm{a}-\mathrm{c}}$ Means within a row with different superscripts differ $(P<0.05)$. ${ }^{1}$ Low SCC (L-SCC; <700,000 cells/mL); medium SCC (M-SCC; from 701,000 to 1,500,000 cells/mL); and high SCC (H-SCC; >1,501,000 cells/mL). 
Low

electrophoretic

mobility

peptides

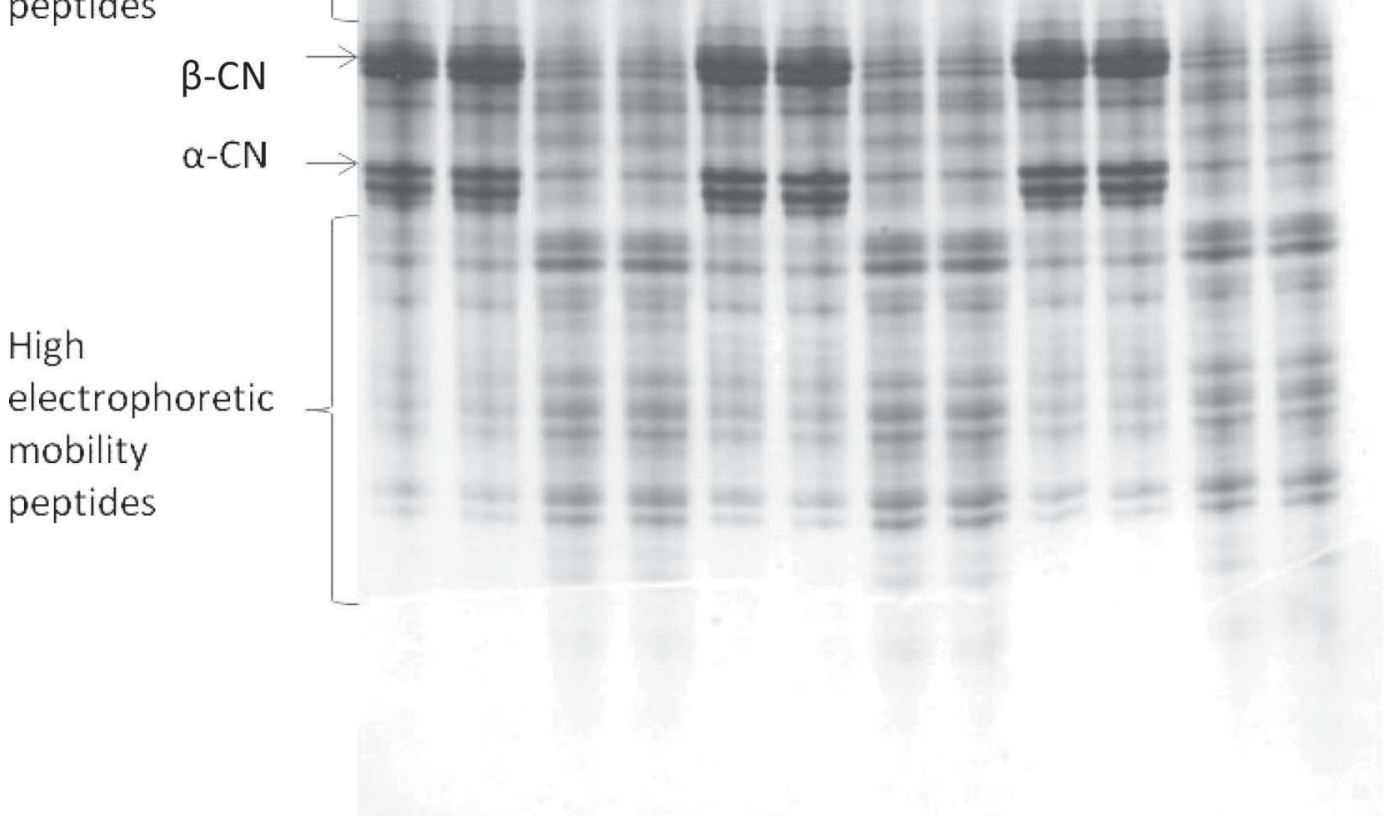

Figure 1. Urea-PAGE electrophoretogram of purified caprine Na-caseinate after incubation with isolated and concentrated macrophages, PMNL, and lymphocytes recovered from a high SCC milk sample at $37^{\circ} \mathrm{C}$ at $\mathrm{pH} 6.5$. Lanes $1,2=$ caprine NaCN incubated with PMNL for 6 h; lanes 3, $4=$ caprine NaCN incubated with PMNL for 4 d; lanes 5, $6=$ caprine NaCN incubated with macrophages for 6 h; lanes $7,8=$ caprine $\mathrm{NaCN}$ incubated with macrophages for $4 \mathrm{~d}$; lanes $9,10=$ caprine NaCN incubated with lymphocytes for 6 h; lanes 11 , $12=$ caprine $\mathrm{NaCN}$ incubated with lymphocytes for $4 \mathrm{~d}$.

concentrated macrophages, PMNL, and lymphocytes recovered from a $\mathrm{H}-\mathrm{SCC}$ milk sample at $37^{\circ} \mathrm{C}$ at $\mathrm{pH} 6.5$ for $6 \mathrm{~h}$ and $4 \mathrm{~d}$ are presented in Figure 1. It can be seen that prolonged incubation with any of the isolated cell populations resulted in extensive proteolysis of the $\mathrm{CN}$ and the appearance of a range of bands that presumably represent proteolysis products.

The mean levels of intact $\alpha_{\mathrm{s}^{-}}$and $\beta-\mathrm{CN}$ in sodium caseinate incubated (at $\mathrm{pH} 6.5 ; 37^{\circ} \mathrm{C}$ ) with isolated and concentrated macrophages PMNL, or lymphocytes from individual caprine milk samples with different SCC, are shown in Table 3. Apart from leukocyte type, SCC influenced CN hydrolysis patterns, which may be reflected in differences in levels of intact $\alpha_{s^{-}}$and $\beta-\mathrm{CN}$. In particular, $\alpha_{\mathrm{s}}-\mathrm{CN}$ was hydrolyzed almost completely, with only $5 \%$ left after $4 \mathrm{~d}$ of incubation.

Mean levels of low electrophoretic mobility peptides after incubation of sodium caseinate (at $\mathrm{pH} 6.5 ; 37^{\circ} \mathrm{C}$ ) with isolated and concentrated macrophages, PMNL, or lymphocytes from individual caprine milk samples

Table 2. Least squares means analysis of plasmin, elastase, and cathepsin D activities in individual caprine milk samples with different levels of $\mathrm{SCC}^{1}$

\begin{tabular}{lccccc}
\hline Item & $\begin{array}{c}\text { L-SCC } \\
(\mathrm{n}=525)\end{array}$ & $\begin{array}{c}\text { M-SCC } \\
(\mathrm{n}=560)\end{array}$ & $\begin{array}{c}\text { H-SCC } \\
(\mathrm{n}=515)\end{array}$ & SEM & $\begin{array}{c}\text { Effect, } \\
P \text {-value }\end{array}$ \\
\hline Plasmin $(\mathrm{U} / \mathrm{mL})$ & $7.98^{\mathrm{a}}$ & $11.33^{\mathrm{b}}$ & $19.07^{\mathrm{c}}$ & 0.10 & $<0.001$ \\
Cathepsin D $(\mathrm{U} / \mathrm{mL})$ & $0.42^{\mathrm{a}}$ & $0.84^{\mathrm{c}}$ & $0.70^{\mathrm{b}}$ & 0.02 & $<0.05$ \\
Elastase $(\mathrm{U} / \mathrm{mL})$ & $0.10^{\mathrm{a}}$ & $0.19^{\mathrm{c}}$ & $0.14^{\mathrm{b}}$ & 0.01 & $<0.05$ \\
\hline
\end{tabular}

${ }^{\mathrm{a}-\mathrm{c}}$ Means within a row with different superscripts differ $(P<0.05)$.

${ }^{1}$ Low SCC (L-SCC; <700,000 cells/mL); medium SCC (M-SCC; from 701,000 to 1,500,000 cells/mL); and high SCC (H-SCC; >1,501,000 cells/mL). 
Table 3. Mean levels of intact $\alpha_{\mathrm{s}^{-}}$and $\beta$-CN in sodium caseinate incubated for $4 \mathrm{~d}$ with isolated and concentrated macrophages, PMNL, and lymphocytes from individual caprine milk samples with different levels of SCC ${ }^{1}$

\begin{tabular}{|c|c|c|c|c|c|}
\hline Item & L-SCC & M-SCC & H-SCC & SEM & $\begin{array}{l}\text { Effect, } \\
P \text {-value }\end{array}$ \\
\hline \multicolumn{6}{|l|}{$\beta-\mathrm{CN}(\%)$} \\
\hline Macrophages & $43.80^{\mathrm{b}}$ & $50.45^{\mathrm{c}}$ & $33.82^{\mathrm{a}}$ & 0.50 & $<0.001$ \\
\hline PMNL & $45.47^{\mathrm{b}}$ & $43.95^{\mathrm{b}}$ & $35.05^{\mathrm{a}}$ & 0.60 & $<0.001$ \\
\hline Lymphocytes & $44.90^{\mathrm{b}}$ & $34.13^{\mathrm{a}}$ & $36.85^{\mathrm{a}}$ & 0.80 & $<0.001$ \\
\hline \multicolumn{6}{|l|}{$\alpha_{\mathrm{s}}-\mathrm{CN}(\%)$} \\
\hline Macrophages & $6.40^{\mathrm{a}}$ & $9.57^{\mathrm{c}}$ & $5.41^{\mathrm{a}}$ & 1.20 & $<0.001$ \\
\hline PMNL & $7.74^{\mathrm{b}}$ & $8.83^{\mathrm{c}}$ & $5.49^{\mathrm{a}}$ & 1.18 & $<0.001$ \\
\hline Lymphocytes & $6.84^{\mathrm{a}}$ & $6.45^{\mathrm{a}}$ & $5.51^{\mathrm{a}}$ & 1.50 & $<0.001$ \\
\hline
\end{tabular}

${ }^{\mathrm{a}-\mathrm{c}}$ Means within a row with different superscripts differ $(P<0.05)$.

${ }^{1}$ Low SCC (L-SCC; <700,000 cells/mL); medium SCC (M-SCC; from 701,000 to 1,500,000 cells $/ \mathrm{mL}$ ); and high SCC (H-SCC; >1,501,000 cells/mL).

with different SCC are shown in Figure 2. For cells recovered from L-SCC samples, higher levels of low electrophoretic mobility peptides, detected in the upper part of the urea-PAGE electrophoretograms, were found irrespective of leukocyte type; for cells isolated from MSCC milk, the same fraction was highest $(P<0.001)$ in sodium caseinate incubated with macrophages and lowest in the case of incubation with lymphocytes. In cells from H-SCC samples, low electrophoretic mobility peptides level reached $30 \%$ of the incubated sodium caseinate, irrespective of leukocyte type added.

Mean levels of high electrophoretic mobility peptides from sodium caseinate incubated $\left(\mathrm{pH} 6.5 ; 37^{\circ} \mathrm{C}\right)$ with isolated and concentrated macrophages, PMNL, or lymphocytes from individual caprine milk samples with different SCC are shown in Figure 3. For samples prepared from L-SCC milk, the percentage of peptides located in the lower part of the gel was higher $(P<$

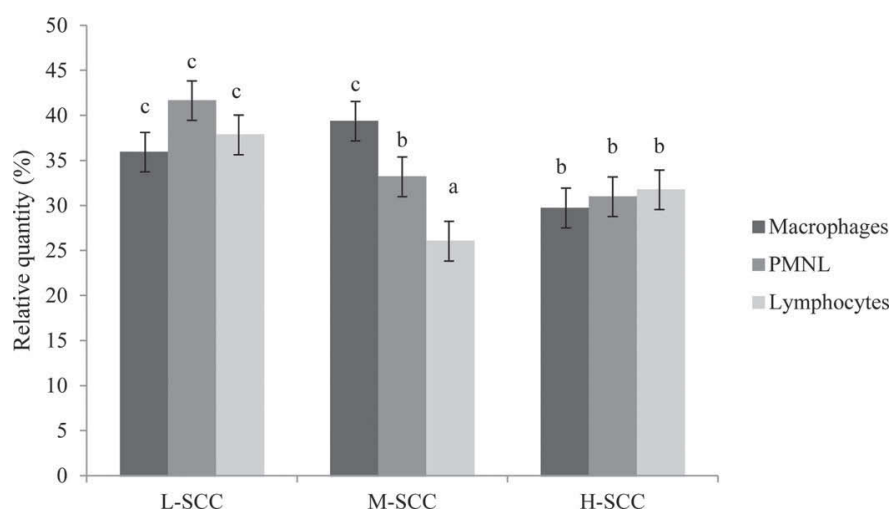

Figure 2. Mean levels of low electrophoretic mobility peptides produced from sodium caseinate incubated for $4 \mathrm{~d}\left(\mathrm{pH} 6.5 ; 37^{\circ} \mathrm{C}\right)$ with isolated and concentrated macrophages, PMNL, and lymphocytes isolated from individual caprine milk samples with different levels of SCC. Low SCC (L-SCC; <700,000 cells/mL); medium SCC (M-SCC; from 701,000 to $1,500,000$ cells $/ \mathrm{mL}$ ); and high SCC (H-SCC; >1,501,000 cells $/ \mathrm{mL})$. ${ }^{\mathrm{a}-\mathrm{c}}$ Means values with different letters differ $(P<0.05)$. Error bars indicate SEM.
0.001) in sodium caseinate incubated with lymphocytes and lower in sodium caseinate incubated with macrophages; for samples prepared from M-SCC milk, this fraction was higher in sodium caseinate incubated with PMNL and macrophages. Within H-SCC milk samples the level of these peptides was not different among leukocyte types and was always higher than L-SCC and M-SCC groups.

\section{DISCUSSION}

In caprine milk samples with SCC greater than 700,000 cells $/ \mathrm{mL}$, PMNL comprised about $60 \%$ of the cell population, which was expected because of their recruitment in the mammary gland to fight bacterial infection (Tian et al., 2005). The PMNL are recruited from the blood for the immune defense of the mammary gland; for this purpose, the resident macrophages

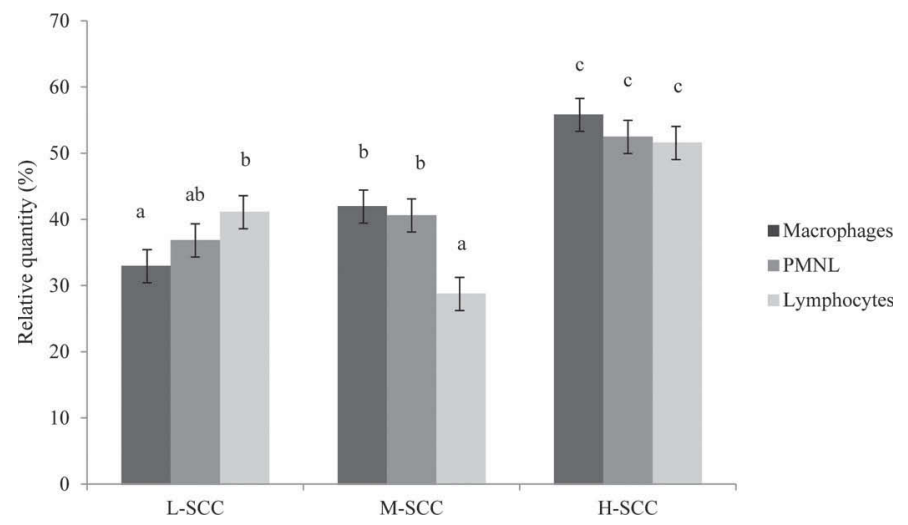

Figure 3. Mean levels of high electrophoretic mobility peptides produced from sodium caseinate incubated for $4 \mathrm{~d}\left(\mathrm{pH} 6.5 ; 37^{\circ} \mathrm{C}\right)$ with isolated and concentrated macrophages, PMNL, and lymphocytes isolated from individual caprine milk samples with different levels of SCC. Low SCC (L-SCC; $<700,000$ cells/mL); medium SCC (M-SCC; from 701,000 to 1,500,000 cells/mL); and high SCC (H-SCC; $>1,501,000$ cells $/ \mathrm{mL}) .{ }^{\mathrm{a}-\mathrm{c}}$ Means values with different letters differ $(P$ $<0.05)$. Error bars indicate SEM. 
release cytokines, eicosanoids, acute phase proteins, and chemoattractants that direct migration of PMNL (Sladek and Rysanek, 2010). The increase in levels of macrophages in caprine milk between L-SCC and HSCC samples confirms their critical role not only in the initiation but also in the maintenance and resolution of inflammatory process (Sladek and Rysanek, 2010). Most of the recruited PMNL in milk are relatively young and undergo slow apoptosis processing pathways and consequently survive longer (Mehrzad et al., 2004).

In caprine milk samples with low SCC $(<300,000$ cells $/ \mathrm{mL}$ ), it was found that $30 \%$ of milk PMNL underwent cell death by apoptosis or necrosis (Tian et al., 2005). The fact that the highest percentage of nonviable PMNL cells was found in L-SCC samples supports the hypothesis that this cell population represents the resident PMNL and is able to modulate the innate immune defense. Albenzio and Caroprese (2011) found a positive correlation between SCC and level of nonviable PMNL in ovine milk samples with SCC lower than 500,000 cells/mL, suggesting that young PMNL were not recruited into the mammary gland. In M-SCC and $\mathrm{H}-\mathrm{SCC}$ milk samples, the reduction in levels of nonviable PMNL confirmed the active role of viable PMNL cells in the mammary gland response to immune stimuli. In individual ovine milk samples, lymphocyte levels did not differ between milk samples with $<500,000$ and $>1,000,000$ cells $/ \mathrm{mL}$, suggesting that lymphocytes are not recruited in the ovine mammary gland in response to inflammation and that resident lymphocytes may be able to mount an immune response (Albenzio and Caroprese, 2011).

In the present study, the lymphocytes detected in caprine milk samples with greater than 700,000 cells/ $\mathrm{mL}$ seem not to be recruited in the mammary gland, probably as a consequence of the migration of PMNL and macrophages across the mammary epithelium into the milk cistern. However, caprine milk undergoes modifications to lymphocyte populations following mammary infections, with the population of lymphocytes being enriched in memory and effector $\mathrm{T}$ lymphocytes and depleted in T helper and B cells (Guiguen et al., 1996).

Indigenous proteolytic enzymes in ovine and caprine milk mainly comprise the plasmin system, cathepsin D, and elastase (Moatsou, 2010). The role of indigenous proteolytic enzymes in $\mathrm{CN}$ breakdown in ovine milk is well documented (Albenzio et al., 2004, 2005, 2009), whereas very limited studies have been reported for caprine milk (Santillo et al., 2009). In this study, plasmin was confirmed to be the major proteolytic enzyme in caprine milk, and its activity was correlated with SCC (Somers et al., 2003; Hamed et al., 2012). In caprine milk, macrophages could be the agent responsible for such increases in plasmin activity; results on ovine milk suggest that plasmin activity is dependent on plasminogen activators released by milk macrophages (Albenzio et al., 2004). Also in caprine milk, Politis et al. (1994) showed that somatic cells contain one type of plasminogen activator (urokinase-type plasminogen activator) associated with the macrophage cell membranes. In bovine milk, the general consensus is that proteolysis in low SCC milk is dominated by plasmin, with a minor contribution from cathepsin D; however, as the SCC increases, the relative significance of plasmin decreases, and the relative activity of other enzymes increases (Kelly et al., 2006). In ovine milk, cathepsin $\mathrm{D}$ is associated with PMNL and macrophages, whereas elastase is mainly associated with PMNL (Albenzio and Santillo, 2011). In caprine milk, the positive correlation between cathepsin D activity and PMNL level confirmed that PMNL may be the main source of this protease. It has been reported that cathepsin D is ostensibly a lysosomal enzyme, although it is present in acid whey in free form (Larsen et al., 1996). The high relative activity of elastase and cathepsin D in M-SCC milk could reflect the first activation of the immune response at mammary gland level, consistent with the recruitment of PMNL by macrophages that act a fast but nonspecific defense. In caprine milk samples with SCC $>1,501,000$ cells $/ \mathrm{mL}$, the minor contribution to the overall indigenous proteolytic activities of cathepsin $\mathrm{D}$ and elastase could be explained by the activation of specific immune mechanisms that represent the second line of the immune response at mammary gland level.

Proteolysis in milk occurs in the udder before milking (Saeman et al., 1988) and during milk storage (Albenzio et al., 2009). Albenzio et al. (2005) and Santillo et al. (2009) studied activities of indigenous proteolytic enzymes in ovine and caprine milk on sodium caseinate, to simulate the proteolytic activity in small ruminant milk during storage before cheese manufacture. In the present study, the evaluation of CN hydrolysis was performed on isolated leukocytes pooled to reach a fixed concentration, to allow evaluation of the qualitative differences in proteolytic pattern associated with each leukocyte population. As expected, $\alpha_{\mathrm{s}^{-}}$and $\beta-\mathrm{CN}$ underwent significant proteolysis after $4 \mathrm{~d}$ of incubation, confirming the role of indigenous proteolytic enzymes associated with leukocytes to proteolysis in caprine milk. In a previous study, Santillo et al. (2009) found higher percentage reduction of the intact $\alpha_{s}-\mathrm{CN}$ due to a higher relative percentage of $\alpha_{\mathrm{s}}$-CN as substrate for plasmin activity. Furthermore, it has been reported that a rapid proteolysis of $\alpha_{\mathrm{s}}$-CN fraction occurred by plasmin from bovine blood and milk (Bastian and Brown, 1996). In this study $\alpha_{\mathrm{s}}-\mathrm{CN}$ was more susceptible to hydrolyses for the presence not only of plasmin 
but also of a complex pattern of indigenous enzymes, freed from leukocyte cells. The significant increase in $\beta$-CN breakdown associated with SCC was also observed by Ham et al. (2010) in goat and cow milks and by Jaeggi et al. (2003) in ewe milk. This evidence demonstrated that concomitant increase in SCC plays a key role in $\mathrm{CN}$ breakdown, apparently due its effect on indigenous protease activity in milk (Hamed et al., 2012). It is worth noting that the minor percentage of low electrophoretic mobility peptides in H-SCC samples at the end of incubation could be explained by the subsequent hydrolysis of this fraction, which in turn could explain the higher concentration of high mobility peptides found in the same group. The latter fraction is presumably composed of peptides deriving from breakdown of $\alpha_{\mathrm{s}^{-}}$and $\beta-\mathrm{CN}$, and their subsequent hydrolysis end products, and may be considered as an index of advanced proteolytic process. The proteolytic pattern showed a more complex profile in the M-SCC samples; lymphocytes contributed minimally to $\mathrm{CN}$ breakdown, whereas macrophages and PMNL were principally responsible for proteolysis of $\mathrm{CN}$, presumably due to their higher level of cathepsin D and elastase activities. In H-SCC caprine milk samples, the intense proteolysis is attributed mainly to plasmin, which appeared to be the principal indigenous proteolytic activity.

\section{CONCLUSIONS}

The application of a specific SCC threshold for caprine milk should take into account the role of leukocytes, both in the evolution of the immune status of mammary gland and in the definition of a satisfactory milk processing quality. In caprine milk, a value of 700,000 cells/mL may represent a threshold for changes in the immune status of mammary gland; the increase in levels of PMNL, macrophages, and viable PMNL cells could be considered as functionally related to the activation of the mammary gland immune system. The concomitant increase in proteolytic indigenous enzymes influenced the hydrolysis of $\mathrm{CN}$. As for bovine and ovine milk, plasmin appeared to be the predominant activity in caprine milk, and its activity was correlated with SCC and, in particular, with levels of macrophages. Cathepsin D activity was positively correlated with PMNL level, confirming the contribution of this cell type to the activity of the main milk acid indigenous protease. Proteolysis patterns of sodium caseinate incubated with isolated and lysed leukocyte cell types showed more complex profile for samples prepared from milk with greater than 700,000 cells $/ \mathrm{mL}$. The study of proteolysis profiles may be useful in predicting changes in milk quality before cheesemaking, and it appears that PMNL and macrophages were primarily respon- sible for hydrolysis of $\mathrm{CN}$, through their lysosomal enzymes. The $\alpha_{\mathrm{s}}-\mathrm{CN}$ was the more susceptible fraction to hydrolysis by the indigenous proteases.

\section{ACKNOWLEDGMENTS}

The present work was supported by the Italian Ministry of Agricultural, Food and Forestry Policies (MIPAAF).

\section{REFERENCES}

Albenzio, M., A. Campanozzi, M. D’Apolito, A. Santillo, M. Pettoello Mantovani, and A. Sevi. 2012a. Differences in protein fraction from goat and cow milk and their role on cytokine production in children with cow's milk protein allergy. Small Rumin. Res. 105:202-205.

Albenzio, M., and M. Caroprese. 2011. Differential leukocyte count for ewe milk with low and high somatic cell count. J. Dairy Res. $78: 43-48$.

Albenzio, M., M. Caroprese, R. Marino, A. Muscio, A. Santillo, and A. Sevi. 2006. Characteristics of Garganica goat milk and Cacioricotta cheese. Small Rumin. Res. 64:35-44.

Albenzio, M., M. Caroprese, R. Marino, A. Santillo, L. Taibi, and A. Sevi. 2004. Effects of somatic cell count and stage of lactation on the plasmin activity and cheese-making properties of ewe milk. J. Dairy Sci. 87:533-542.

Albenzio, M., M. Caroprese, A. Santillo, R. Marino, A. Muscio, and A. Sevi. 2005. Proteolytic patterns and plasmin activity in ewe milk as affected by somatic cell count and stage of lactation. J. Dairy Res. 72:86-92.

Albenzio, M., A. Santillo, M. Caroprese, F. d'Angelo, R. Marino, and A. Sevi. 2009. Role of endogenous enzymes in proteolysis of sheep milk. J. Dairy Sci. 92:79-86.

Albenzio, M., and A. Santillo. 2011. Biochemical characteristics of ewe and goat milk: Effect on the quality of dairy products. Small Rumin. Res. 101:33-40.

Albenzio, M., A. Santillo, M. Caroprese, D. Ruggieri, M. Ciliberti, and A. Sevi. 2012b. Immune competence of the mammary gland as affected by somatic cell and pathogenic bacteria in ewes with subclinical mastitis. J. Dairy Sci. 95:3877-3887.

Albenzio, M., A. Santillo, M. Caroprese, L. Schena, D. E. Russo, and A. Sevi. 2011. Composition, indigenous proteolytic enzymes and coagulating behaviour of ewe milk as affected by somatic cell count. J. Dairy Res. 78:442-447.

Andrews, A. T. 1983. Proteinases in normal bovine milk and their action on caseins. J. Dairy Res. 50:45-55.

Bastian, E. D., and R. J. Brown. 1996. Plasmin in milk and dairy products: An update. Int. Dairy J. 6:435-457.

Bevilacqua, C., P. Martin, C. Candalh, J. Fauquant, M. Piot, A. M Roucayroll, F. Pilla, and M. Heyman. 2001. Goat's milk of defective alpha (s1)-casein genotype decreases intestinal and systemic sensitization to beta- lactoglobulin in guinea pigs. J. Dairy Res. $68: 217-227$.

Blakesley, R. W., and J. A. Boezi. 1977. A new staining technique for proteins in polyacrylamide gels using Coomassie brilliant blue G250. Anal. Biochem. 82:580-582.

Boulaaba, A., N. Grabowski, and G. Klein. 2011. Differential cell count of caprine milk by flow cytometry and microscopy. Small Rumin. Res. 97:117-123.

Caroprese, M., A. Marzano, L. Schena, and A. Sevi. 2008. Immunomagnetic positive selection of macrophages in ovine milk. J. Dairy Sci. 91:1908-1912.

EFSA (European Food Safety Authority). 2005. Opinion on the usefulness of somatic cell counts for safety of milk and milk derived products from goats. EFSA J. 305:1-19.

EU (European Union). 2004. Regulation (EC) No. 853/2004 of the European Parliament and of the Council of 29 April 2004 laying 
down specific hygiene rules for food of animal origin. Off. J. Eur. Union L 226:22-82.

Guiguen, F., T. Greenland, E. Pardo, G. Panaye, and J. F. Mornex. 1996. Flow cytometric analysis of goat milk lymphocytes: Subpopulations and adhesion molecule expression. Vet. Immunol. Immunopathol. 53:173-178.

Ham, J. S., S. G. Lee, S. G. Jeong, M. H. Oh, D. H. Kim, and Y. W. Park. 2010. Characteristics of Korean-Saanen goat milk caseins and somatic cell counts in comparison with Holstein cow milk counterparts. Small Rumin. Res. 93:202-205.

Hamed, H., A. J. Trujillo, B. Juan, B. Guamis, A. ElFeki, and A. Gargouri. 2012. Interrelationships between somatic cell counts, lactation stage and lactation number and their influence on plasmin activity and protein fraction distribution in dromedary (Camelus dromedarius) and cow milks. Small Rumin. Res. 105:300-307.

IDF. 1995. Enumeration of Somatic Cells. FIL-IDF Standard No. 148A. Int. Dairy Fed., Brussels, Belgium.

Jaeggi, J. J., S. Govindasamy-Lucey, Y. M. Berger, M. E. Johnson, B. C. McKusick, D. L. Thomas, and W. L. Wendorff. 2003. Hard ewe's milk cheese manufactured from milk of three different groups of somatic cell counts. J. Dairy Sci. 86:3082-3089.

Kelly, A. L., and P. L. H. McSweeney. 2002. Indigenous proteinases in milk. Adv. Dairy Chem. 1:494-519.

Kelly, A. L., F. O'Flaherty, and P. F. Fox. 2006. Indigenous proteolytic enzymes in milk: A brief overview of the present state of knowledge. Int. Dairy J. 16:563-572.

Larsen, L. B., C. Benfeldt, L. K. Rasmussen, and T. E. Petersen. 1996 Bovine milk procathepsin D and cathepsin D: coagulation and milk protein degradation. J. Dairy Res. 63:119-130.

Mehrzad, J., L. Duchateau, and C. Burvenich. 2004. Viability of milk neutrophils and severity of bovine coliform mastitis. J. Dairy Sci. $87: 4150-4162$

Moatsou, G. 2010. Indigenous enzymatic activities in ovine and caprine milks. Int. J. Dairy Technol. 63:16-31.

Mulvihill, D. M., and P. F. Fox. 1977. Proteolysis of $\alpha_{s 1} 1^{-c a s e i n}$ by chimosin: Influence of $\mathrm{pH}$ and urea. J. Dairy Res. 44:533-540.

Park, Y. W. 2010. Improving goat milk. Pages 304-346 in Improving the Safety and Quality of Milk. Vol. 2. Improving Quality in Milk Products. M. Griffiths, ed. Woodhead Publ., Cambridge, England.
Park, Y. W., and M. R. Guo. 2006. Goat milk products: Processing technology, types and consumption trends. Pages 59-106 in Handbook of Milk of Non-Bovine Mammals. Y. W. Park and G. F. W. Haenlein, ed. Blackwell Publ., Ames, IA.

Politis, I. 1996. Plasminogen activator system: Implication for mammary cell growth and involution. J. Dairy Sci. 79:1097-1107.

Politis, I., J. H. White, K. O'Hare, B. Zavizion, J. Gilmore, and W. Caler. 1994. Distribution of plasminogen activator forms in fractions of goat milk. J. Dairy Sci. 77:2900-2906.

Raynal-Ljutovac, K., A. Pirisi, R. de Crémoux, and C. Gonzalo. 2007. Somatic cells of goat and sheep milk: analytical, sanitary, productive and technological aspects. Small Rumin. Res. 68:126-144.

Saeman, A. I., R. J. Verdi, D. M. Galton, and D. M. Barbano. 1988. Effect of mastitis on proteolytic activity in bovine milk. J. Dairy Sci. 71:505-512.

Santillo, A., A. L. Kelly, C. Palermo, A. Sevi, and M. Albenzio. 2009 Role of indigenous enzymes in proteolysis of casein in caprine milk. Int. Dairy J. 19:655-660.

SAS Institute Inc. 2011. SAS/STAT User's Guide: Statistics. Version 9.2 ed. SAS Inst. Inc., Cary, NC.

Sevi, A., M. Albenzio, L. Taibi, D. Dantone, S. Massa, and G. Annicchiarico. 1999. Changes of somatic cell count through lactation and their effects on nutritional, renneting and bacteriological characteristics of ewe's milk. Adv. Food Sci. 21:122-127.

Shapiro, S. S., and M. Wilk. 1965. An analysis of variance test for normality. Biometrika 52:591-601.

Sladek, Z., and D. Rysanek. 2010. Apoptosis of resident and inflammatory macrophages before and during the inflammatory response of the virgin bovine mammary gland. Acta Vet. Scand. 52:12-25.

Somers, J. M., B. O'Brien, W. J. Meaney, and A. L. Kelly. 2003. Heterogeneity of proteolytic enzyme activities in milk samples of different somatic cell count. J. Dairy Res. 70:45-50.

Tian, S. Z., C. J. Chang, C. C. Chang, H. C. Peh, M. C. Huang, J. W. Lee, and X. Zhao. 2005. Comparison of morphology, viability, and function between blood and milk neutrophils from peak lactating goats. Can. J. Vet. Res. 69:39-45. 